\title{
Family Farming and Biodiesel: rural development in Central-Western Brazil
}

\section{Agricultura Familiar e Biodiesel: desenvolvimento rural no Centro Oeste brasileiro}

Marcos Rodrigues - Ph.D. in Environment and Social Development from the Centre for Advanced Amazonian Studies of the Federal University of Pará (NAEA/UFPA). Professor at Universidade Federal da Amazônia (UFRA). E-mail: marcos.rodrigues.adm@gmail.com.

Felipe Deodato da Silva e Silva - Ph.D. in Sustainable Development from the Centre for Sustainable Development at the University of Brasília (CDS/UnB). Professor at Instituto Federal de Mato Grosso (IFMT). E-mail: felipe.silva@bag.ifmt.edu.br.

David Costa Correia Silva - Ph.D. in Environment and Social Development from the Centre for Advanced Amazonian Studies of the Federal University of Pará (NAEA/UFPA). Professor at Universidade Federal Rural da Amarônia (UFRA). E-mail: davidcorreiasilva@hotmail.com.

\section{Resumo}

A produção de biodiesel no Brasil iniciou-se em 2005. O Programa Nacional de Produção e Uso do Biodiesel (PNPB) objetivou integrar agricultores familiares como fornecedores de matéria-prima para as indústrias de biodiesel, reduzindo assim a pobreza e promovendo o desenvolvimento rural. A integração de agricultores familiares foi revista devido a predominância da soja na cadeia de produção do biodiesel. Este estudo teve como objetivo comparar os mecanismos institucionais desenvolvidos por agricultores familiares e agentes econômicos em Mato Grosso a partir de dois diferentes estudos que ocorreram entre 2011 e 2013. O contexto teórico da Nova Economia Institucional foi necessário para identificar os mecanismos contratuais e de mercado desenvolvidos - arrendamento de maquinário, adicional de preço, fontes de financiamento e os pacotes tecnológicos - para aumentar a renda familiar e contribuir para o sucesso do PNPB em Mato Grosso. A presença destes mecanismos em diferentes regiões indica a difusão do conhecimento na rede produtiva da soja.

\section{Palavras-chave}

Agricultura Familiar. Biodiesel. Instituições. Desenvolvimento Rural. Centro-Oeste Brasileiro.

\begin{abstract}
Biodiesel production in Brazil commenced in 2005. The National Program for Production and Use of Biodiesel (PNPB) sought to integrate family farmers as raw material providers to biodiesel firms, thereby reducing poverty and promoting rural development. The integration of family farmers was reviewed given the predominance of soybean in the biodiesel supply chain. This study sought to compare institutional mechanisms enacted in two regions in the State of Mato Grosso in order to increase family farmers' participation in biodiesel market. We selected some municipalities in the northern and southeast macro regions of Mato Grosso as study cases. The theoretical framework of the New Institutional Economics was necessary to identify the contractual and market mechanisms developed (machinery leasing, additional prices, funding sources, and technological package) to increase income among families and contribute to the success of the PNPB in Mato Grosso. The presence of these mechanisms in different regions was indicative of innovation diffusion across the soybean network.
\end{abstract}

\section{Keywords}

Family Farming. Biodiesel. Institutions. Rural Development. Central-Western Brazil 


\section{INTRODUCTION}

Public policies formulated to reduce poverty in rural areas can cause varying results in different institutional settings. Hence, the influence of public policies on increasing rural income is contingent upon a situational approach (BJÄRSTIG; SANDSTRÖM, 2017; FERNÁNDEZ PORTILLO; SANTOS CARRILLO, 2015). Theoretical and practical changes regarding the role of agriculture in development influence the manner in which public policies are formulated (FREITAS; FREITAS; DIAS, 2012). In Brazil, the national government promotes the emerging biodiesel sector, which serves as an alternative path for achieving rural development.

In 2005, the National Program for Production and Use of Biodiesel (PNPB) was launched to develop the biodiesel industry. This public policy established the following three main goals for the biodiesel sector: i) energy matrix diversification by ensuring a mixture of biodiesel and mineral diesel; ii) improvements in the relative importance of renewable energy in the national energy matrix; and iii) development of formal institutions to encourage biodiesel firms to purchase raw material from family farmers.

Although the production of biodiesel increased during the first decade of the program, the remaining goals set by the PNPB were not achieved. Biodiesel production in Brazil increased from $69,000 \mathrm{~m}^{3}$ in 2006 to more than 3.937 million $\mathrm{m}^{3}$ in 2015. However, the main biodiesel input was soybean oil, which represented $77.31 \%$ of the total national biodiesel input (ANP, 2016).

The federal government changed the institutional environment by developing a Social Fuel Seal (SFS) in order to certify firms that guaranteed the participation of family farmers in the PNPB. As a consequently, certified firms received some benefits such as tax reductions and prioritized benefits during biodiesel auctions. The objective was to incentivize biodiesel firms to purchase family farmers' crops as raw material. Consequently, there has been a yearly increase in participation among family farmers since the creation of the PNPB. However, although 104, 295 families participated in 2011, there was decrease in participation to 72,485 families by 2015 (BRASIL, 2016).

Based on the literature reviewed, the structure and perspectives of the Brazilian biofuels supply chain were assessed (PADULA et al., 2012; POUSA; SANTOS; SUAREZ, 2007). Other studies focused on the environmental consequences of expanding biodiesel production and its raw materials, which were sourced primarily from large-scale agricultural production (CASTANHEIRA et al., 2014; RAVINDRANATH et al., 2011) and, the effectiveness of biodiesel policies 
in integrating family farmers that possessed diverse raw materials in the context of income generating (FINCO; DOPPLER, 2011; LEITE et al., 2013). Studies were also conducted on the social and environmental impacts in response to local productive arrangements for biodiesel production and requisite arrangements for supply chains of castor oil in semi-arid areas (LEÃO; HAMACHER; OLIVEIRA, 2011; RODRIGUES et al., 2009). Soybean production for biodiesel was also studied from the perspective of New Institutional Economics (NEI), as in the case of Minas Gerais state (DAL BELO LEITE et al., 2015; WATANABE; BIJMAN; SLINGERLAND, 2012). In this context, some studies have focused on institutional arrangement in regions with traditional production of soybean on small scales (WATANABE; BIJMAN; SLINGERLAND, 2012).

Soybean cropping in Mato Grosso was found to be capital intensive, possessed economies of scale, and was strongly integrated with trading companies. While large farm operations were predominant in this arrangement, the biodiesel program made family farmers' entry a reality.

The aim of this study was to determine the institutional mechanisms developed to integrate family farmers that produced soybean for the biodiesel market. In addition to the knowledge accumulated, we sought to identify the formal relationships in the biodiesel supply chain in Mato Grosso that permitted economic viability of soybean production. We hypothesized that institutional mechanisms such as contracts and formal rules were adopted in response to the prevailing institutional conditions based on interactions among biodiesel firms, small-scale farmers and the government to ensure feasibility of soybean production among small-scale family farmers in response to the raw material requirements stipulated in the biodiesel program.

\section{THEORETICAL APPROACH}

\subsection{NEW INSTITUTIONAL ECONOMICS AND BIODIESEL}

Transactions are the basic units of an economy. Exchanges and interactions among sellers and buyers define demand and prices. These transactions are instantaneous and tend to ensure equilibrium between supply and demand. This mechanical perspective, based on neoclassical economic theory, was considered as unreal. Coase (1937) argued that it was necessary to consider specific conditions during negotiations, for example, the institutions.

Institutions are an amalgam of formal and informal rules that influence social interactions and regulate the development of a society (NORTH, 1990, 
1994). Studies on institutions are commonly subdivided into the institution environment and institutional arrangement subfields in conformity with the level of analysis (WILLIAMSON, 1996). The institutional environment refers to the political, social and legal rules that guide development, while institutional arrangement are rules followed by economic agents in a given market to cooperate and/or compete (NORTH, 1990; WILLIAMSON, 1996).

Another important concept is the structure of governance, which refers to a system of rules with enforcement capabilities of regulating a specific transaction. The challenge of concretizing these transactions can be overcome by institutional changes. Essentially, formal rules change faster than informal rules in accordance with the behaviours and habits of a given society. The enforcement capability of government to implement such changes is critical for the survival of economic agents.

Institutional changes may be implemented to propel changes in the development trajectory of a business activity, a sector or even a country. The government is the main entity, which mobilizes financial resources and technologies, sets formal rules, and stipulates incentives for restructuring production (HORLINGS; KANEMASU, 2015; MURAKAMI et al., 2015). Institutional changes can also assume the role of a bureaucratic mechanism to foster development (NGOASONG; KIMBU, 2016).

Institutional changes also affect the scope of economic agents. Institutional mechanisms are developed to ensure competitiveness in the face of a complex environment, which requires a review of a given productive paradigm. The innovation system is premised on the development of institutional mechanisms that surmount barriers when the productive paradigm faces a new institutional environment.

An economic transaction involves a wide range of agents that may not necessarily have common goals, but may be affected by institutional changes. However, it is possible to develop co-operative mechanisms in order to achieve a mutual goal, which does not involve competition. The innovation systems concept involves the creation and diffusion of innovations across a network of institutions, thereby contributing to the overall achievement of goals (BERGEK et al., 2008). Moreover, institutional innovations, which are also referred to as technological innovations, play a critical role in the establishment of networks (KLERKX; AARTS; LEEUWIS, 2010). In this regard, networks can decrease the transaction cost of negotiations in order to facilitate transactions that were previously unachievable. 
In the context of our case study, the network is the coordinating system, which facilitates the diffusion of innovations in the agricultural system. Biodiesel production is a challenge to firms and small farmers. The new institutional environment requires a diffusion of innovations in order to overcome barriers imposed by the productive paradigm, which seeks to ensure market access for small producers.

Biodiesel firms ensure competitiveness of small farmers given their importance in the PNPB. However, the integration of such farmers requires institutional provisions. Such provisions also guarantee profitability and the achievement of a high productivity of soybean. The network disseminates this solution, thus, facilitating soybean production among family farms. Trading companies play an important role in determining the agricultural paradigm. However, economic agents must develop institutional mechanisms for small farmers to adapt to such paradigm without altering such arrangement.

Each individual goal becomes achievable through co-operation and coordination, which are essentials for the development and maintenance of innovation systems (ROBERTSON; LANGLOIS, 1995). Network coordination is contingent upon trading companies working as a bridge between farmers and suppliers. In reality, trading companies provide capital and purchase agricultural produce. In some cases, they are the very biodiesel companies. However, small farms are required to assimilate and adapt to innovations. Government institutions are expected to support innovation initiatives by farmers and companies in order to promote rural development and strengthen productivity of biodiesel in Brazil.

The entire group of economic agents interacts in the market and provides institutional solutions to problems identified. Although agents have different goals, they prefer to co-operate when the perceived advantages of collaboration are higher than competing individually. A strengthening of co-operative relationships occurs through the diffusion of innovation in the production supply chain, thus, increasing market competitiveness.

\subsection{THE BRAZILIAN BIODIESEL PROGRAM AND AGRICULTURAL DEVELOPMENT}

At the onset of the $21^{\text {st }}$ century, prices of mineral diesel and the debate regarding alternative energy resurfaced. It has been recognized that Brazil has a great potential for producing biofuels. As a consequence, the government stimulated development of alternative energy from alcohol and biodiesel to replace fossil fuel, thus, mitigating the impacts associated with price fluctuations (GOLDEMBERG; LUCON, 2008; PINTO JR. et al., 2007). 
In recent years, Brazil has developed its biodiesel sector given the availability of lands and expertise in seed oil production. In 2005, the Brazilian government enacted the PNPB to stimulate the biodiesel production. To achieve the PNPB's goals, the Brazilian government created a number of institutional incentives for biodiesel companies to buy raw materials from family farmers.

In Brazil, biodiesel is mixed with mineral diesel, and is regulated by the government through biodiesel auctions. In this regard, the government estimates demand and, as such, stipulates the volume of biodiesel that can be purchased at auctions. The government created the SFS to recognize biodiesel firms that promote participation of family farms in conformity with the requirements of the program. The seal is given to firms whenever the costs of raw materials from family farms are higher than a minimum percentage of the total costs of raw materials. The government reserves $80 \%$ of the total biodiesel sales for certified firms. Additionally, the seal qualify certified firms to enjoy lower tax benefits. In the Midwest, where Mato Grosso is located, a 15\% minimum of raw materials must be purchased from family farmers.

The PNPB sought diversification of raw materials produced by family farmers. Alternative crops cultivated on family farms were castor bean and oil palm. This strategy was informed by a technical feasibility assessment on cultivating these crops on a small scale in semiarid regions. There are no significant results in response to this policy at the national level mainly because soybean oil remains the principal raw material for the biodiesel industry. This is followed by animal fat (Figure 1). Soybean is produced for animal feedstock and exportation, while its oil is used for multiple purposes, including biodiesel (CREMONEZ et al., 2015).

Figure 1 - Raw materials used for the production of biodiesel (B100) (2006 - 2015)

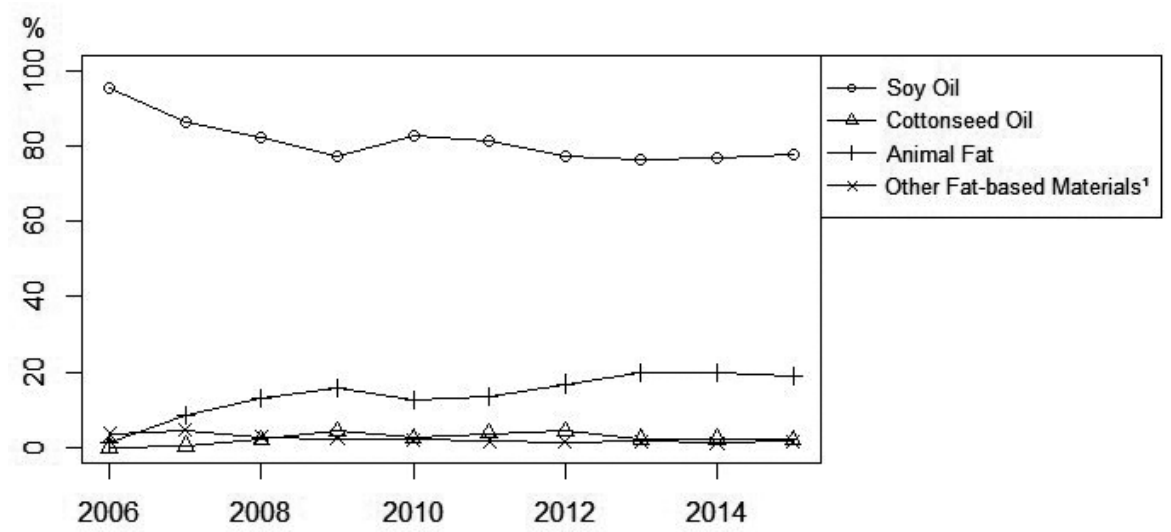

Data Source: ANP (2016).

${ }^{1}$ Includes palm oil, peanut oil, turnip-feed oil, sunflower oil, castor oil, sesame oil, and oil used after frying foods. 
In 2013, soy oil production reached its highest historical output of 2.23 million $\mathrm{m}^{3}$ despite having the second lowest relative share in raw materials for biodiesel in Brazil (Figure 1). Since 2006, only animal fat has witnessed a significant change in the share of raw materials for biodiesel. Soy oil remains the principal raw material in the industrial process. Alternatives that were initially planned for family farms, which were grouped under "other fat-based materials", have been growing modestly primarily in other regions and states of the country, such as in semi-arid areas and in the state of Minas Gerais.

The market structure in Mato Grosso is conducive for the production of biodiesel from soy oil supplied. The largest output of soybean is recorded in Mato Grosso, where a significant increase from 16.7 million tons in 2005/2006 to 26.4 million tons in 2013/2014 has been achieved. This corresponds to $30.7 \%$ of the total production of soybean in Brazil (CONAB, 2017). Producers of this crop are traditionally large farmers in this state. However, despite this level of output, soybean was the main oil seed provided by family farmers. Raw material goals were not achieved even under diversification. However, this program was important to family farmers excluded from agribusiness in Mato Grosso.

The establishment of biodiesel plants based on soy oil is more advantageous because of higher outputs and lower asset specificity in Mato Grosso. However, the PNPB obliges firms to purchase produce from family farmers, thus increasing the specificity of this asset. Other raw materials, such as castor beans and palm oil could have higher asset specificity. Mato Grosso does not produce these raw materials on large scales. Furthermore, biodiesel plants have been designed specifically for soybean. Thus, the asset specificity for different raw materials will increase transaction costs.

\section{METHODOLOGY OF THE STUDY}

This paper is based on an analysis of innovation diffusion and the New Institutional Economics (NIE) theoretical framework. We have discussed the institutional environment of the Brazilian Biodiesel Program with specific reference to the State of Mato Grosso. This followed by a comparative analysis of two regions that are geographical different, but yet similar given the economic importance of agriculture. To compare these regions, we analyse the institutional arrangements that have led to innovations in order to integrate small farmers into the soybean supply chain.

In order to compare these two regions, we use the case study research approach (YIN, 2009) to focus on the Brazilian state of Mato Grosso, which 
has the largest agricultural production at the national level. Soybean production stands out with 27.85 million tons, which was equivalent to $28.58 \%$ of the national output in 2015 (IBGE, 2019). This state is an important biodiesel producer, as confirmed by an output of 845,670 $\mathrm{m}^{3}$ in 2015 (ANP, 2016). Historically, the market coordination is based on contractual relations among large farmers and trading companies.

The objective has been to assess the inclusion of farmers in the biodiesel program and their method of managing oilseed production. Sixty-one (61) small farmers were interviewed. This total consisted of farmers from the following two macro regions, which reflected the case studies (1) the northern Mato Grosso and (2) southeastern Mato Grosso (Figure 2).

Figure 2 - Macro regions and municipalities in Mato Grosso assessed in this study

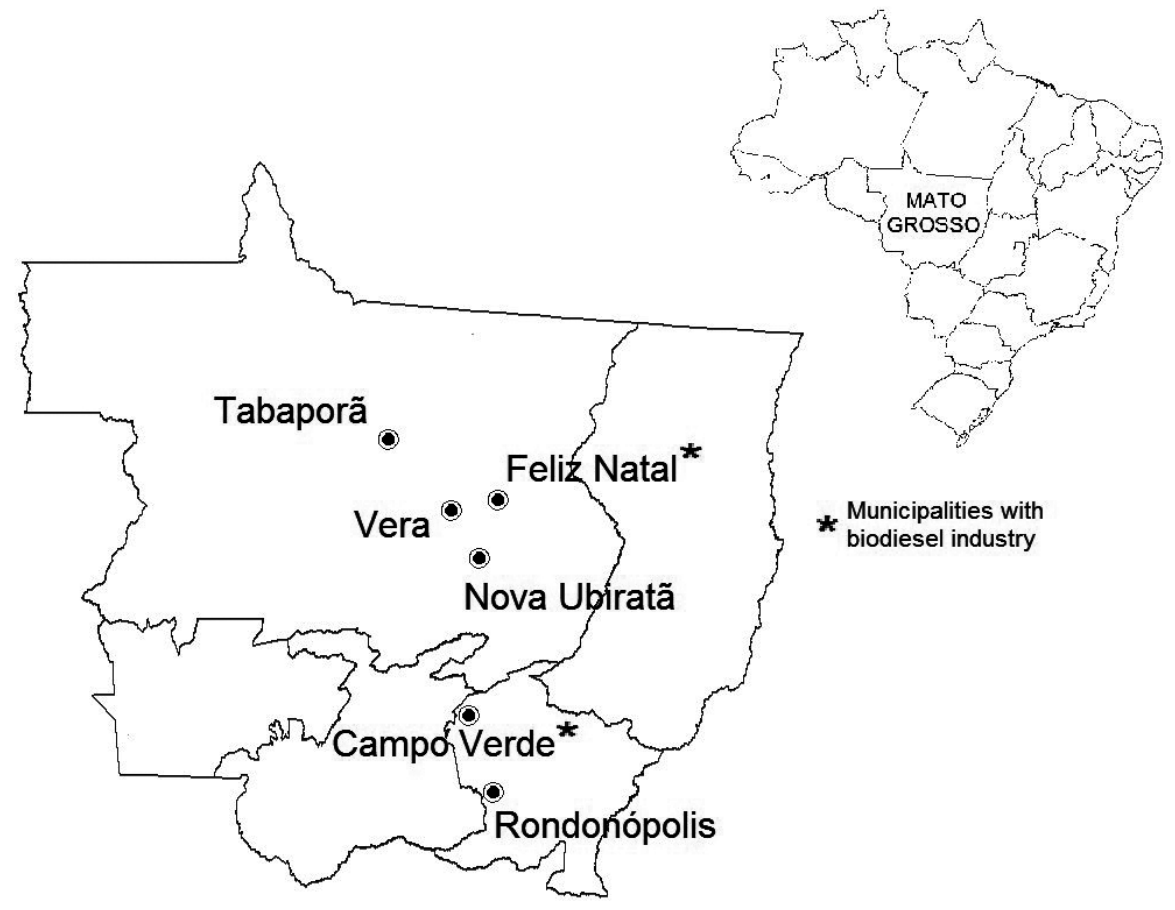

Source: Elaborated by the Authors.

In the northern macro region, the research focused on family farmers from the following four municipalities: (1) Feliz Natal, (2) Nova Ubiratã, (3) Tabaporã, and (4) Vera. We interviewed 25 families that produced soybean for a biodiesel co-operative industry, which is located in this region. The data elicited included information regarding soybean production from 2011 to 2013. In the 
south-eastern macro region, we focused on family farmers in Carimã settlement, which is located in Rondonópolis. Thirty-six (36) families were interviewed and data was gathered on soybean cropping in 2012 and about the biodiesel industry in Campo Verde.

Questionnaires were administered to biodiesel companies to elicit information regarding the capacity of firms, raw material requirements, their suppliers, and their commercial relationships with family farmers. Questionnaires administered to the farmers sought to identify institutional mechanisms of coordination (contracts, prices, machinery leasing, and funding sources) with companies and the soybean supply chain, which facilitated the production of soybean for the biodiesel companies. These variables were analysed and interpreted in the context of institutional economics based on the presence of mechanisms to reduce transaction and production costs, improve soybean network efficiency and to permit income generation among families.

The data gathered from both studies was first described separately by presenting the regional characteristics and institutional mechanisms adopted by family farmers. This was followed by a more rigorous comparative analysis, with a focus on innovations that were diffused in the soybean network.

\section{RESULTS AND DISCUSSION}

\subsection{SMALL FARMERS AND THE BIODIESEL INDUSTRY IN NORTHERN MATO GROSSO}

Since the 1960s, the northern macro region has grown in response to government policies that promoted human resettlement from southern Brazil to the Amazon. With an abundance of forest species, the timber industry grew in the first two decades followed by cattle rearing. During the 1990s, modernized agriculture flourished in response to the decline of the timber industry. Conducive environmental conditions for soybean cultivation were found in this region (CAMPOS, 2012). As result, soybean cultivation increased rapidly over the past 25 years. It was feasible for only large firms to produce this crop as they benefited from economy of scale. However, this productive arrangement is has been changing since the unset of the biodiesel program, which demands that family farmers participate as suppliers in this supply chain.

In the first study conducted in northern Mato Grosso, we identified a small biodiesel plant, which was organized as a co-operative involving both small and large-scale farmers. According to the co-operative, the following were 
two major challenges among seekers of a Social Fuel Seal i) few farmers were able to produce soybean on a small scale and, ii) consequently, other biodiesel firms offered incentives such as paying higher prices for soybean and funding production by small farmers, who secured exclusive contracts. In order to compete with these firms, the co-operative must also offer some incentives to retain their small farmers.

Formal institutional obligations established among firms and small farmers, such those related to technical assistance and contracts, were completely fulfilled. Incentives were detailed in contracts regarding farmers' integration into the firms. The first incentive was a $20 \%$ increase in the minimum guaranteed price, which was never lower than that established by the Program of Price Warranty for Family Farmers. Another incentive was marked by an additional contractual incentive of $\mathrm{R} \$ 20,00$ per ton of soybean oil. In this regard, firms sought to establish a long-term relationship with small farmers. It was found that better prices paid to such farmers rendered it more profitable to produce soybean in spite of the technological challenges previously discussed.

The co-operative also offered small farmers fertilizers, pesticides and finance for soil amelioration in return for payments in kind (soybean). These incentives increase crop productivity, farmers' income and the quantity of raw material supplied to biodiesel plants. Limited access to inputs is a barrier to rural development and the success of the PNPB (LEITE; SILVA; VAN ITTERSUM, 2014). The PNPB permitted the inclusion of these expenditures in the costing of raw material acquisition, which as result facilitated the achievement of a minimum percentage cost relative to the total value of the firms' raw material costs ${ }^{1}$.

Productivity among small farmers was comparable to that of large farmers, which on average was 3.06 tons of soybeans per hectare during the three years that were considered in this assessment. High productivity was attributed to contractual standards and the technological package acquired from trading companies that financed part of the producers' costs. In northern Mato Grosso, $56 \%$ of small farmers were funded by these companies, 16\% obtained credit from the government program (PRONAF), and the other 28\% obtained credit from other sources, including self-financing. These companies played a pivotal role in financing mainly large firms that incurred higher costs for soybean production in Mato Grosso. They also offered solutions to small farmers by serving as a mechanism to maximize outputs.

The benefits small farmers enjoyed triggered increases in output and income. However, economy of scale in soybean productive arrangement persisted in this

\footnotetext{
This minimum is set at 15\% in Mato Grosso.
} 
model. In such a case the initial investment was so high that large farms were required to ensure economic feasibility for soybean production. Harvester is an essential and the most expensive machinery in soybean production. In northern Mato Grosso, 52\% of family farmers reduced their investment by substituting machinery acquisition for contracts that outsourced harvesting services. In this regard, the following two contractual schemes were observed i) a payment of $6 \%$ of total harvest plus fuel, or ii) a payment of $10 \%$ of total harvest. In both schemes family farmers substituted the investment in machinery by outsourcing harvesting services, which increased production costs, but payment were made in kind (with soybean) rather than in cash.

\subsection{SETTLEMENT PROJECT IN SOUTH-EASTERN MATO GROSSO AND BIODIESEL}

In the south-eastern macro region we studied the relationships among farm owners from Carimã settlement and biodiesel firms. The Carimã settlement is located in the municipality of Rondonópolis. In this municipality, there are three biodiesel firms, including a large biodiesel plant in Mato Grosso. However, these firms did not establish a commercial relationship with the producers in Carimã. Instead, farm owners supplied their produce to a biodiesel company in the City of Campo Verde, which is located at a distance of 138 kilometres from Rondonópolis.

The Carimã settlement is located 50 kilometres south of Rondonópolis. It was established in 1996 with 194 families that have individual properties that have an average size of 20 hectares. The main economic activities included livestock rearing, crop production and tourism. From the 194 properties, 53 or 27.31\% produced soybean in 2010, 2011 and 2012 to supply the biodiesel company in Campo Verde. Approximately $72.73 \%$ of the owners allocated more than half of their properties for soybean cultivation, thus, less land was allocated for the cultivation of other crops. In order to complement their families' income, some individuals worked on other non-family farms outside the settlement.

The majority of owners $(72.73 \%)$ submitted the Declaration of Aptitude (DAP) to PRONAF. The remaining farmers did not possess land ownership. Farmers were denied credit to produce soybean because the biodiesel firms had already provided financial support. In Carimã, soybean production had a similar characteristic to that produced in northern Mato Grosso, where producers rented services to sow seeds, apply agrochemicals, and harvest. Only one family from Carimã had the machinery required to harvest effectively its own soybeans. 
A biodiesel company in Campo Verde had the technology to process vegetable oil from soybean, cottonseed, and beef tallow. This company established partnerships with family farmers from other cities in Mato Grosso and with other famers from southern Brazil. Like firms from the northern macro region, this firm also incentivized family producers by purchasing an additional $\mathrm{R} \$ 20,00$ per ton, which was a price determined by the Ministry of Agrarian Development. This price was introduced under the PNPB institutional context, which increased the costs to biodiesel firms while increasing income among family farmers of the agricultural sector.

Biodiesel firms were of the opinion that supply from family farms in Mato Grosso was insufficient to maintain the minimum percentage as the Social Fuel Seal agreement. Consequently, this stimulated the demand for family production outside of this state. The main motivation to purchase raw materials from family producers was to obtain the seal's benefits and to promote social responsibility by ensuring that family famers participated in the biodiesel sector. However, the main challenge were the bureaucratic legal processes, such as those for contracts development and the preparation of supporting documents for compliance, so that families could participate.

The firm offered six technical assistances yearly- four of which were individual, while two being collective. They focused on technical information on production and did not cater for other issues, such as finances, management, and legal issues. Family farmers reported that they neither did they read nor understood the contracts signed with biodiesel firms. In addition, they confirmed that they had trouble in understanding legal documents, which were required by government entities as proof of commercial relationships. Therefore, biodiesel firms are charge with additional responsibilities of resolving such bureaucratic activities on behalf of the family farmers.

\subsection{SYNTHESIS: BIODIESEL AND SMALL FARMERS IN SOYBEAN CULTIVATION}

Mato Grosso is characterized by a setting of multiple relationships among different economic stakeholders including farmers, suppliers and government. It was possible to identify intermediate stakeholders, the trading companies, which sourced soybeans cultivated by farmers for export or industrial processing. They played another important role in the biodiesel market in terms of contributing to its development and ensuring that soybean oil remained the main raw material for biodiesel. 
Trading companies played a pivotal role in determining the agricultural paradigm in Mato Grosso, where there was a predominance of large soybean, cotton and corn farms. Agricultural intensification did not only increase soil productivity, but also increased the total cost, which was reduced under large-scale operations. This large-scale soybean production was related to the experience curve (NEIJ et al., 2003), which showed that the unitary cost of production decreased as production increased.

The traditional soybean cropping system involved costly investments in technology and machinery. Large farms and trading companies characterized the institutional framework of the soybean market. These companies provided capital to farmers along with a technological package and purchased soybean produced through binding contracts (ADAMS; YELLEN, 1976; BRUM et al., 2011). The high capital investments that were required for large-scale production of soybean imposed barriers to family farmers' participation in the biodiesel program.

High production costs and economy of scale were the main factors that deterred small farmers from producing soybean, hence a predominance of large farmers. However, due to scarcity of capital, they were financed by the trading companies, which served as a bridge, with binding contracts, between farmers and suppliers (BRUM et al., 2011; RODRIGUES; MARQUEZIN, 2014). The contract ensured a technological package that guaranteed profitability among owners and large farms. This structure of governance reinforced the paradigm of soybean production by larger farms, while excluding smaller ones.

Brazil's emerging biodiesel program changed its institutional environment, including that related to family farmers as one of raw materials suppliers to biodiesel firms. In order to integrate family farms into Mato Grosso's soybean supply chain, institutional innovations were developed (Table 1) to increase households' income and to attend to productivity demands from biodiesel firms. Table 1 - Institutional innovations for small farmers in Mato Grosso.

\begin{tabular}{lll}
\hline \multicolumn{1}{c}{ Innovation } & \multicolumn{1}{c}{ Benefits } & \multicolumn{1}{c}{ Operation } \\
\hline & $\begin{array}{l}\text { Reduced need for high investments in } \\
\text { machinery; }\end{array}$ & Contracts with others \\
& No need for specialization in & farmers who possessed \\
Harvesting & machinery operation; & reflected a percentage \\
Services & & of harvest and others \\
& & operational costs such as \\
& fuel. \\
\hline
\end{tabular}




\begin{tabular}{|c|c|c|}
\hline $\begin{array}{l}\text { Technical } \\
\text { assistance }\end{array}$ & $\begin{array}{l}\text { Diffused technological practices } \\
\text { regarding cultivation, pesticides, soil } \\
\text { management, use of fertilizers and } \\
\text { harvesting; } \\
\text { Increased productivity; } \\
\text { Reduced production risks; }\end{array}$ & $\begin{array}{l}\text { Professionals in } \\
\text { agricultural science were } \\
\text { contracted by biodiesel } \\
\text { firms to lend support to } \\
\text { small farmers. }\end{array}$ \\
\hline $\begin{array}{l}\text { Funding } \\
\text { (binding } \\
\text { contracts) }\end{array}$ & $\begin{array}{l}\text { Guaranteed provision of necessary } \\
\text { inputs to small farmers, who made } \\
\text { subsequent repayments; } \\
\text { Transferral of funds to small farmers. }\end{array}$ & $\begin{array}{l}\text { Contracts among small } \\
\text { farmers and trading } \\
\text { companies allowed future } \\
\text { payments in product } \\
\text { (soybean). }\end{array}$ \\
\hline $\begin{array}{l}\text { Technological } \\
\text { package }\end{array}$ & $\begin{array}{l}\text { Predetermined agricultural practices; } \\
\text { Provision of binding contracts } \\
\text { Increased productivity; }\end{array}$ & $\begin{array}{l}\text { Predetermined inputs } \\
\text { package established } \\
\text { through binding contracts } \\
\text { among farmers (large } \\
\text { or small) and trading } \\
\text { companies. }\end{array}$ \\
\hline $\begin{array}{l}\text { Price } \\
\text { incentives }\end{array}$ & $\begin{array}{l}\text { Increased market price for soybean } \\
\text { by a percentage or value stipulated } \\
\text { in contracts, thus increasing income } \\
\text { among families } \\
\text { Reduced risk of price changes }\end{array}$ & $\begin{array}{l}\text { Contractual incentives } \\
\text { between small farmers and } \\
\text { biodiesel companies. }\end{array}$ \\
\hline
\end{tabular}

Data Source: Elaborated by the Authors.

As observed in both cases, soybean production was funded by biodiesel firms and/or trading companies, and loan repayments were made in kind. This structure was also observed among large farms. This benefitted farms that required costly modern equipment for soybean cultivation and financing companies, which source soybeans from these farms. Although small farmers required less capital, the funding contracts were based on the same principles.

An important benefit of such funding contracts was the high level of productivity, which is guaranteed because of the technological package, which stipulated inputs (pesticides, fertilizers, and seed quality). Additionally, small farmers gained access to modern methods of cultivation such as crop rotation, zero-tillage farming and the use of transgenic seeds. These farms responded readily to policy and market changes such those relating to funding sources and financial incentives.

The capital-intensive nature of soybean cultivation was the main factor that hindered small farms from achieving economies of scale. In both studies, solutions were identified to avoid this technical difficulty. Frequently, small farmers rented machinery required or paid farmers that possessed the machines required to perform planting and harvesting. Consequently, the reduced capital 
that would have been invested in machinery was allocated to cultural practices, thus increasing productivity and income among farmers. This process amplified the benefits, which would not have been so significant had the commercial relationship been restricted to firms and family farmers.

Other studies revealed that in order to avoid high costs of soybean production small farmers share machinery costs (WATANABE; BIJMAN; SLINGERLAND, 2012). However, our study found a substantial difference regarding an absence of social capital in Mato Grosso. The presence of trading companies restricted collaborative actions among small farmers. Problems associated with the unavailability of machinery were readily resolved though market-based solutions such as machinery renting, thus soybean is immediately sold to trading companies following harvest.

A legal incentive was also added to such market-based solutions. The price of the soybean increased by $\mathrm{R} \$ 20.00$ per ton, thus increasing the families' income and rendering soybean production less risky in response to price fluctuations. Although such price elevation meant higher costs for biodiesel firms, such were offset by the benefits of the Social Fuel Seal, which guaranteed lower taxes and preferential access during biodiesel auctions.

Although farmers were faced with capital-intensive investments, they proved that soybean farming was feasible among small-scale farmers through the adoption of institutional innovations. Data from farmers in Mato Grosso confirmed that on average, between 2010/2011 and 2012/2013 cropping cycles, annual soybean profits were $\mathrm{R} \$ 38,635.60$ per farmer (standard deviation of \pm $\mathrm{R} \$ 14,539.39)$. Thus, monthly incomes ranged from $\mathrm{R} \$ 1,807.29$ to $\mathrm{R} \$ 5,323.50$ in accordance with farm size. Larger farms enjoyed economies of scale, which institutional innovations were unable to change. Consequently, farmers were pressured to increase production in order to increase income. Economies of scale obliged increased use of agrochemicals, which caused many health problems among farmers. Such agrochemicals also contaminated grains, soil, air and water (BRANDO et al., 2013; PIGNATI; OLIVEIRA; SILVA, 2014).

The legal regulations of the PNPB charged biodiesel firms with the responsibility of ensuring an inclusion of family producers in this sector. While biodiesel firms decided the crop and the method, which family farmers must follow to produce, they overlooked the subsistence system. For example, in the Carimã half of cultivated land was allocated to soybean, which decreased the land allocated for food crop cultivation. While this commercial relationship increases income among families, it posed a major challenge to assess improvements in rural welfare. From a commercial perspective, family farmers are well assimilated 
into the biodiesel and soybean sector. However, it is necessary to further assess whether income gained from soybean allows improvements in other areas, such as health, food security and education.

In both studies, the availability of technical assistance to all farmers was observed. This increased the supply chain's competitiveness rather than simply being a legal obligation to firms. Technical difficulties that small-scale soybean farmers normally faced declined because of knowledge diffusion by firms that provided the technological package. This action did not only increase family farmers' income, in response to a higher productivity at a level comparable to that of large-scale farmers, but also supplied more raw materials to firms. Nevertheless, technical assistance was limited because it failed to focus on other issues, such as finances, management, and legal issues that were critical to guarantee income generation among family farmers.

Cropping methods and practices were diffused through technological innovation, thereby increasing productivity among small farms. Contracts (machinery renting, binding contracts and price incentives) should also be considered in an agricultural innovation system (KLERKX; AARTS; LEEUWIS, 2010). The existent network among large and small farmers, trading firms, biodiesel companies and government developed institutional mechanisms, which fostered production of soybean among small farmers in Mato Grosso, thus changing the traditional paradigm that set barriers due to economies of scale. However, progress is necessary in order to integrate more family farmers into the biodiesel program.

The expansion of soybean cultivation in response to the biodiesel program did not only contribute to rural development, but also intensified the debate regarding the associated impacts on human health and the environment of agrochemicals. Additionally, the pressure for new arable lands across the Amazon and the Cerrado increases deforestation (BARONA et al., 2010; FEARNSIDE, 2001). Once gaining land access, soybean farmers injudiciously use agrochemicals, which cause health problems and contaminate the soil, air and water (PIGNATI; OLIVEIRA; SILVA, 2014).

\section{CONCLUSIONS}

Policies developed to reduce poverty in rural areas can achieve varying results in different settings. The PNPB proposed to integrate family farmers in the biodiesel supply chain as a strategy to enhance their income. However, with the preference and predominance of firms in soy oil, the social goal of the 
PNPB was at risk, as soybean cultivation required agricultural mechanization for economy of scale, thus limiting entry among small farmers.

This study aimed to assess and describe institutional arrangement created in Mato Grosso to foster soybean cultivation among family farmers and to include them into the biodiesel sector. Despite the challenges associated with economy of scale in soybean cultivation, the PNPB was successful in integrating family farmers from Mato Grosso in the biodiesel sector.

The results confirmed the hypothesis that family farmers, firms and the government developed alternative institutional mechanisms, such as machinery renting, inputs supply, diffusion of scientific knowledge and best agricultural practices, and technical assistance in order to surmount economic barriers associated with soybean cultivation. In addition, legal incentives on prices had a positive impact on family income earned by small farmers. These strategies yielded higher productivity and promoted financial success among small farmers. Therefore, institutional solutions developed in Mato Grosso represented a new path for soybean production among small farmers whenever social capital is weak or absent.

Rural development could be achieved from perspectives other than that of economic success. Further studies on others social issues, which are important to development, such as food security, health and education, are needed considering the fact that soybean cultivation poses a serious threat to the environment and human health.

\section{REFERENCES}

ADAMS, W. J.; YELLEN, J. L. Commodity Bundling and the Burden of Monopoly. The Quarterly Journal of Economics, v. 90, n. 3, p. 475-498, ago. 1976.

\section{ANP. Anuário Estatístico Brasileiro do Petróleo, Gás Natural e} Biocombustíveis: 2016. Rio de Janeiro: ANP, 2016.

BARONA, E. et al. The role of pasture and soybean in deforestation of the Brazilian Amazon. Environmental Research Letters, v. 5, n. 2, p. 024002, 2010. BERGEK, A. et al. Analyzing the functional dynamics of technological innovation systems: A scheme of analysis. Research Policy, v. 37, n. 3, p. 407-429, abr. 2008.

BJÄRSTIG, T.; SANDSTRÖM, C. Public-private partnerships in a Swedish rural context - A policy tool for the authorities to achieve sustainable rural development? Journal of Rural Studies, v. 49, p. 58-68, 2017. 
BRANDO, P. M. et al. Ecology, economy and management of an agroindustrial frontier landscape in the southeast Amazon. Philosophical transactions of the Royal Society of London. Series B, Biological sciences, v. 368, p. 20120152, 2013.

BRASIL. Balanço do Selo Combustível Social - 2015. Brasília, DF: MDA, 2016. Disponível em: http://www.mda.gov.br/sitemda/secretaria/saf-biodiesel/ o-selo-combust $\% 25 \mathrm{C} 3 \% 25 \mathrm{AD}$ vel-social. Acesso em: [falta essa informação].

BRUM, L. A. et al. Financement agricole par l'échange grains / intrants : l'impact de la NPR à Sapezal-MT entre 2004 et 2009. Confins, n. 13, p. 7265, 2011.

CAMPOS, I. Limits and Constraints to the Expansion of Soybean Production in the Amazon region. Novos Cadernos do NAEA, Belém, v. 15, n. 2, p. 197-216, 2012.

CASTANHEIRA, É. G. et al. Environmental sustainability of biodiesel in Brazil. Energy Policy, v. 65, p. 680-691, fev. 2014.

COASE, R. H. The Nature of the Firm. Economica, v. 4, p. 386-405, 1937.

CONAB. Séries Históricas - Soja. Brasília, DF: CONAB, 2017. Disponível em: http://www.conab.gov.br/conteudos.php?a=1252\&t=2\&Pagina_objcms conteudos=3\#A_objcmsconteudos. Acesso em: 27 out. 2017.

CREMONEZ, P. A. et al. Biodiesel production in Brazil: Current scenario and perspectives. Renewable and Sustainable Energy Reviews, v. 42, p. 415-428, fev. 2015.

DAL BELO LEITE, J. G. et al. Socioeconomic and environmental assessment of biodiesel crops on family farming systems in Brazil. Agricultural Systems, v. 133, p. 22-34, 2015.

FEARNSIDE, P. M. Soybean cultivation as a threat to the environment in Brazil. Environmental Conservation, v. 28, n. 1, p. 23-38, 2001.

FERNÁNDEZ PORTILLO, L. A.; SANTOS CARRILLO, F. An Analysis of the Quality of the Central American Strategy for Rural Territorial Development (ECADERT) as a Regional Public Policy. Cuadernos de Desarrollo Rural, v. 12, n. 76, p. 83-107, 2015.

FINCO, M. V. A.; DOPPLER, W. The Brazilian Program of Biodiesel and its "Pro-Poor" Strategy: Reality or Dream? A Multi-Dimensional Measurement of Poverty using Fuzzy Sets. Quarterly Journal of International Agriculture, v. 50, p. 133-154, 2011. 
FREITAS, A.; FREITAS, A. F.; DIAS, M. M. Conceptual changes of rural development and its influence on public policy. Revista de Administração Pública, São Paulo, v. 46, n. 6, p. 1575, 2012.

GOLDEMBERG,J.:LUCON,O.Energia,MeioAmbienteeDesenvolvimento. 3. ed. São Paulo: EDUSP, 2008.

HORLINGS, L. G.; KANEMASU, Y. Sustainable development and policies in rural regions; insights from the Shetland Islands. Land Use Policy, v. 49, p. 310321, dez. 2015.

IBGE. Sistema IBGE de Recuperacao automatica-SIDRA. Rio de Janeiro: IBGE, 2019. Disponível em: http:/ /www.sidra.ibge.gov.br/. Acesso em: 1 abr. 2019.

KLERKX, L.; AARTS, N.; LEEUWIS, C. Adaptive management in agricultural innovation systems: The interactions between innovation networks and their environment. Agricultural Systems, v. 103, n. 6, p. 390-400, jul. 2010.

LEÃO, R. R. DE C. C.; HAMACHER, S.; OLIVEIRA, F. Optimization of biodiesel supply chains based on small farmers: A case study in Brazil. Bioresource Technology, v. 102, n. 19, p. 8958-8963, 2011.

LEITE, J. G. D. B. et al. Biodiesel policy for family farms in Brazil: One-size-fitsall? Environmental Science \& Policy, v. 27, p. 195-205, mar. 2013.

LEITE, J. G. D. B.; SILVA, J. V.; VAN ITTERSUM, M. K. Integrated assessment of biodiesel policies aimed at family farms in Brazil. Agricultural Systems, v. 131, p. 64-76, nov. 2014.

MURAKAMI, F. et al. How the Brazilian government can use public policies to induce recycling and still save money? Journal of Cleaner Production, v. 96, p. 94-101, jun. 2015.

NEIJ, L. et al. Experience Curves: a tool for energy policy assessment. Lund, Sweden: Environmental and Energy Systems Studies, 2003.

NGOASONG, M. Z.; KIMBU, A. N. Informal microfinance institutions and development-led tourism entrepreneurship. Tourism Management, v. 52, p. 430-439, fev. 2016.

NORTH, D. C. Institutions, Institutional Change and Economic Performance. New York: Cambridge University Press, 1990.

NORTH, D. C. Economic Performance Through Time. The American Economic Review, v. 84, n. 3, p. 359-368, 1994. 
PADULA, A. D. et al. The emergence of the biodiesel industry in Brazil: Current figures and future prospects. Energy Policy, v. 44, p. 395-405, maio 2012.

PIGNATI, W.; OLIVEIRA, N. P.; SILVA, A. M. C. Surveillance on pesticides: quantification of use and prediction of impact on health, work and the environment for Brazilian municipalities. Ciência \& Saúde Coletiva, Rio de Janeiro, v. 19, p. 4669+, 27 abr. 2014.

PINTO JR., H. Q. et al. Economia da energia: fundamentos econômicos, evolução histórica e organização industrial. Rio de Janeiro: Elsevier, 2007.

POUSA, G. P. A G.; SANTOS, A. L. F.; SUAREZ, P. A Z. History and policy of biodiesel in Brazil. Energy Policy, v. 35, p. 5393-5398, 2007.

RAVINDRANATH, N. H. et al. Biofuel production and implications for land use, food production and environment in India. Energy Policy, v. 39, n. 10, p. 5737-5745, out. 2011.

ROBERTSON, P. L.; LANGLOIS, R. N. Innovation, networks, and vertical integration. Research Policy, v. 24, n. 4, p. 543-562, jul. 1995.

RODRIGUES, G. S. et al. Local productive arrangements for biodiesel production in Brazil- Environmental assessment of small-holder's integrated oleaginous crops management. Journal of Agriculture and Rural Development in the Tropics and Subtropics, v. 110, n. 1, p. 59-71, 2009.

RODRIGUES, M.; MARQUEZIN, W. R. CPR como um instrumento de crédito e comercialização. Revista de Política Agrícola, São Paulo, v. 23, n. 2, p. 40-50, 2014.

WATANABE, K.; BIJMAN, J.; SLINGERLAND, M. Institutional arrangements in the emerging biodiesel industry: Case studies from Minas Gerais-Brazil. Energy Policy, v. 40, p. 381-389, 2012.

WILLIAMSON, O. E. The Mechanisms of Governance. New York: Oxford University Press, 1996.

YIN, R. K. Case Study Research: Design and Methods. 4. ed. [s.l.] SAGE Publications, 2009. 